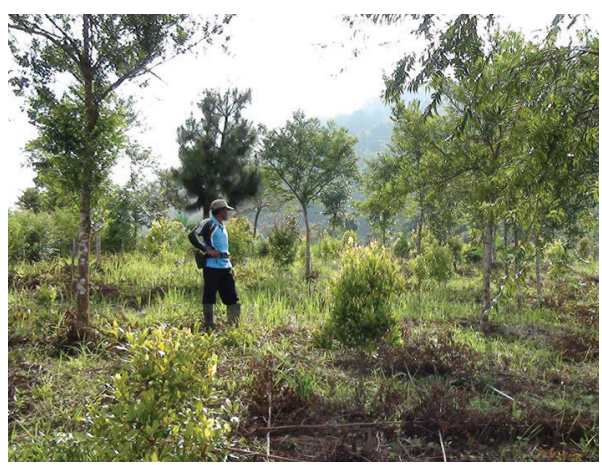

\title{
4.5 Landscapes and the voluntary carbon market, West Sumatra
}

\author{
PAUL BURGERS, HARIS ISKANDAR, BUBUNG \\ ANGKAWIJAYA, RIZKI PANDU PERMANA \\ and AI FARIDA
}

\section{Introduction}

Funding from the voluntary carbon market (VCM) can help to restore productive landscapes, if it is embedded in the local context of traditions and in state governance systems. Restoration efforts under a performance-based VCM programme, if planned well, can also improve livelihoods.

West Sumatra is home to the Minangkabau ethnic group. Indigenous traditions in governing the land continue to be strong. The nagari comprises the village and agricultural land. It is headed by the wali nagari, who is elected by the villagers. Land ownership - or more precisely, the right to use the land - is governed through locally defined rules called adat (von Benda-Beckmann and von Benda-Beckmann 2004). The adatcouncil is the highest governmental body of the nagari. The nagarileaders govern and enforce norms and conventions for the sake of overall prosperity.

Irrigated ricefields, located in valley bottoms, are surrounded by hills consisting of mixed tree-based systems and patches of forest. Ricefields are managed by and inherited through the female line of the family. The surrounding hilly landscape is usually communally managed, either at the level of (extended) families or at the communal nagari level (tanah ulayat nagari). The hutan nagari (nagari forest) is managed at the nagari level. The hilly dryland agricultural areas belong to (extended) families, with two main types of land ownership under the adat system: tribal land (tanah kaum/suku) and king land (tanah rajo).

Tribal land is owned by members of

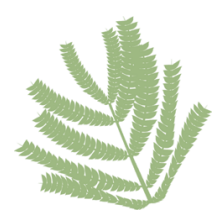

THE APPROACH IS A PRACTICAL WAY FOR COMMUNITIES TO ENGAGE in COLlective ACtion to RESTORE DEGRADED LANDSCAPES. customary groups under the matrilineal system. King land is open-access land; it is owned by whoever initially cultivated it. It can be inherited, but cannot be sold. It is managed and controlled by the oldest man in the

Paul Burgers is Director, $\mathrm{CO}^{2}$ Operate BV; Haris Iskandar is Forest Carbon specialist, International Finance Corporation; Bubung Angkawijaya is Field coordinator, $\mathrm{CO}^{2}$ Operate BV; Rizki Pandu Permana is a Consultant with $\mathrm{CO}^{2}$ Operate BV; and Ai Farida is Lecturer, Geography Department, STKIP PGRI Sumbar. 
matrilineal lineage. These traditional rules are well-defined and are enforced, but formal rules enforced by the state are also in place. Most state forest land is situated beyond the boundaries of the nagari.

In the past, the hills around Singkarak Lake in West Sumatra were covered with productive tree-based systems and forested areas in various configurations. However, recurrent wildfires, severe pests and diseases have changed this landscape into Imperata grasslands. Land degradation and intensified water run-off have become major problems, putting stress on the water supply for rice irrigation. This, in combination with increasingly erratic rainfall patterns caused by climate change, has made these grasslands very susceptible to fire.

Although local communities see the importance of rehabilitating the surrounding hilly landscapes, few individuals make attempts to restore productive tree-based landscapes. Any attempt to successfully restore Imperata grassland landscapes and control the fire risk requires collective action. A coordinated effort, facilitated by a non-local individual or organization, would be required to restore the degraded landscape, as Imperata grasslands have become firmly established since the 1970s.

Collective action must strike a balance between the public good and private benefits. A Netherlands-based social enterprise, $\mathrm{CO}^{2}$ Operate BV (Box 1), took up this challenge and began facilitating the rehabilitation of the degraded lands through community action. Funds from the Food and Agriculture Organization (FAO) supported the communities to develop public benefits in the form of training to restore the forest using Assisted Natural Regeneration (ANR). Carbon funds from $\mathrm{CO}^{2}$ Operate BV enabled private benefits by supporting individual farmers in obtaining and managing economic valuable trees, which were combined with the growing trees as part of forest restoration activities.

\section{Box 1. $\mathrm{CO}^{2}$ Operate: a social enterprise}

A social enterprise is a private company that applies commercial strategies to significantly improve human and environmental well-being. $\mathrm{CO}^{2}$ Operate facilitates the process of carbon neutral production, both in the for-profit and non-profit sector. The fees levied on $\mathrm{CO}_{2}$ emissions are invested in landscape restoration. Economically valuable agroforestry landscapes are established for and with the local population. This makes landscapes more productive, fulfils ecosystem service functions, provides tree products, thus significantly improving rural livelihoods and restoring some biodiversity. $\mathrm{CO}^{2}$ Operate facilitates 136 ha, 55 ha in West Sumatra and the rest in West Java. In June 2014, another 20 ha were added to the West Sumatra sites.

\section{Governing the lands: conflicting provisions}

Many different people and institutions are involved in landscape restoration. Over the years, $\mathrm{CO}^{2}$ Operate has built a strong network of collaboration with important stakeholders in landscape restoration at the national and nagari level in the region (Figure 1). They are all important to the success of restoration activities. 


\section{Figure 1. Stakeholders in landscape restoration}

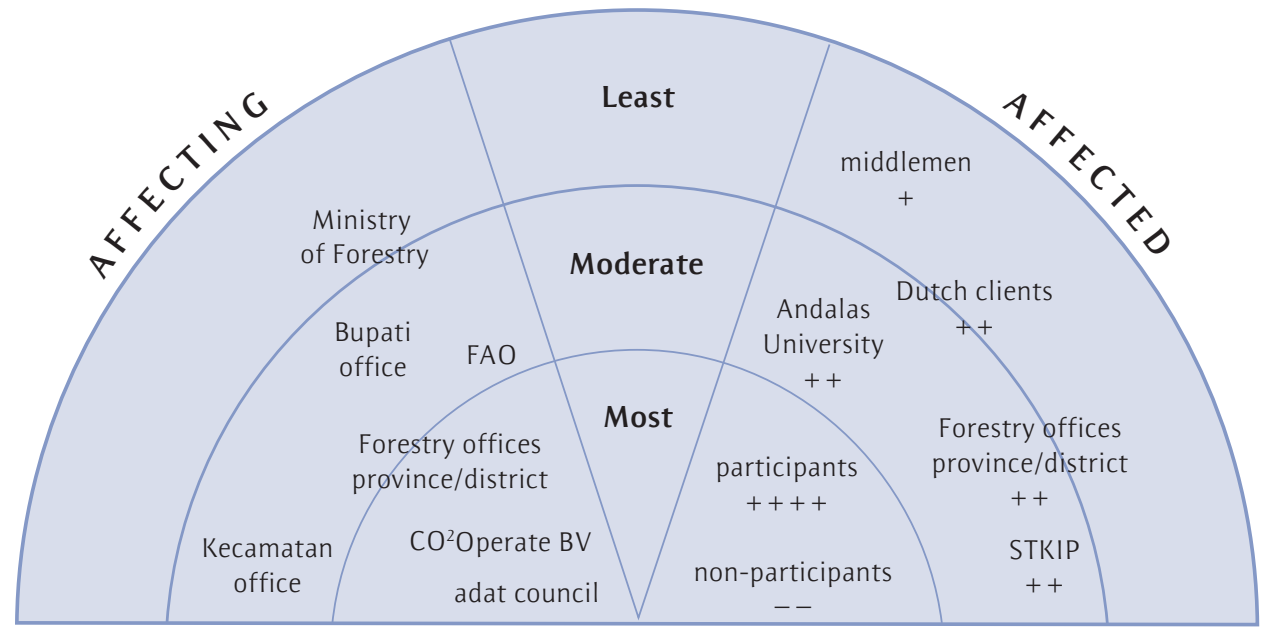

Based on an identification of stakeholders (Figure 1), and the experience with adat and its leaders, $\mathrm{CO}^{2}$ Operate approached the village adat council to see if they wished to ollaborate. The wali nagari, being part of the adat council, would then automatically be involved as well. A process of Free, Prior and Informed Consent (FPIC) was initially carried out to see if the community was interested in the programme. Through FPIC the proposed intervention was fully explained to the community members and local indigenous bodies to determine if they agreed to the project. The FPIC process aimed at providing full and accurate information about the implications of the project on the communities and their customary land, and allowed them to modify components that suited their needs and aspirations.

The performance-based contract was also discussed in detail, including the rights and responsibilities of $\mathrm{CO}^{2}$ Operate, the village adat council and the participating farmers. Once adjustments were made and consensus was achieved, the programme began. Customary norms and conventions guided the VCM institutional structure. Collective action was established by organizing individual farmers in groups; each group was responsible for a specific land area. The farmer groups were coordinated by village elites, in line with the adat hierarchical system.

Unfortunately, the strong influence of the village elites made group members reluctant to speak out to demand corrective action, especially against the elites. After some time, however, group members began to protest against the chieftaincy of the elites, as the leaders seemed to be frustrating rather than supporting the rehabilitation efforts. Protests intensified when a conflict developed due to a delay in handing over the seedlings by the village elites to the members of the farmer groups. Seedlings, which would eventually provide individual economic benefits for the participants, included clove trees, mahogany and various types of fruit trees. These disputes resulted in the forced resignation of the wali nagari as project coordinator; he was also forced to resign as the head of 
the nagari after villagers lodged an official complaint at the governmental district office. As a consequence, the village elite, including adat leaders, also resigned.

The farmers renegotiated the rules and requested a new, simplified and direct agreement between themselves and $\mathrm{CO}^{2}$ Operate. In 2011, the new wali nagari and the adat council agreed that they would not be direct partners in the project. Instead, they suggested that they could have a function in conflict resolution. A new collaboration emerged spontaneously among the farmers, as they formed their own groups, consisting of relatives, neighbours and those willing to work together in equal partnerships. They also chose their own group leader. This increased effective collaboration within and between farmer groups. Due to this revised structure, the participants asked $\mathrm{CO}^{2}$ Operate to support them in applying for formal (cooperative) status for each farmer group. This cooperative structure has shown to be very effective in rehabilitating the land, and has allowed farmers to reap benefits at the level of the cooperative and in individual livelihoods.

\section{Improving rural livelihoods}

The cooperatives work closely together to rehabilitate the land. Annual carbon payments under the VCM contract are made to the cooperatives, not to individual farmers. The livelihoods of individual farmers have started to improve significantly now that various tree products can be harvested, cloves being the most valuable. The first small harvest of the four-year-old planted clove trees earned each farmer $€ 1,000$. This revenue was generated from about 15 producing trees. Since they planted around 200 trees, and a future average harvest could be $40 \mathrm{~kg}$ per tree, their annual income from clove trees might reach around $€ 8,000$ (at current price levels). This is very high when compared to the official 2014 minimum wage for West Sumatra, which is $€ 100$ per month. In addition, planted fruit trees provide food, while surpluses are sold in the local market. Long-term sustainability comes from the planting of mahogany trees as a living fence, planted as a saving for their children.

Additional income is generated at the cooperative level. The annual carbon payments are invested in production activities. One cooperative invested its carbon revenues in a cattle-feeding programme. The sale of the first animal brought substantial new funds into the cooperative, which will be used for further economic development.

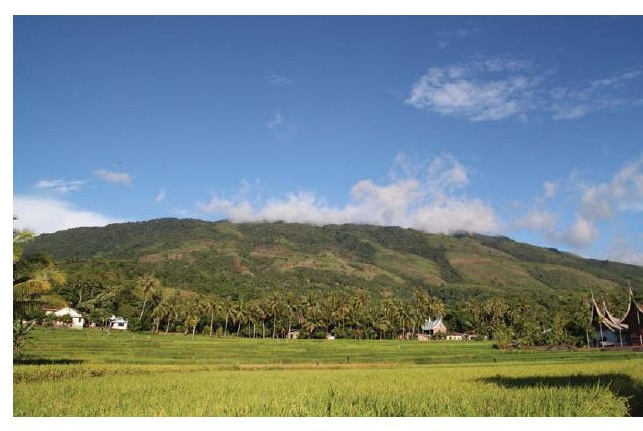
Another cooperative, made up of all women, used the carbon revenue to cultivate ginger in between the growing trees as a short-term food and cash crop. Other cooperatives began to convert additional land for rehabilitation. One cooperative recently initiated a savings programme. Every week, members put 20,000 rupiah (€1.5) from the earnings of the agroforestry products into the cooperative's account. The formalized cooperative structures have also enabled the groups to apply for government funds. One group received funds to build a paved path for easier access to their fields with a motorcycle. Another cooperative received 50 million rupiah (around 
$€ 3,200$ ) from the forestry department to set up a village nursery with 35,000 seedlings, including timber trees, fruit trees and clove trees. Besides adding more land, seedlings were sold to individual villagers. Although these villagers were not part of the VCM programme, they saw the benefits of the restoration activities. They also practice ANR, which they learned from current VCM participants.

\section{Carbon stock performance}

In a VCM programme, an important component in restoring a productive landscape is the extent to which the $\mathrm{CO}_{2}$ sequestration meets the compensation targets of the clients. They requested that $\mathrm{CO}^{2}$ Operate invest in the rehabilitation in support of their carbon neutral mission. In December 2013 a carbon assessment was conducted in collaboration with Andalas University and the teacher's college STKIP, both in Padang. All participants received field training to assess carbon stocks above ground, below ground and in the litter and the soil. The university's laboratory facilities were used to analyze carbon in the litter and soil.

The data revealed that $64 \%$ of the carbon was stored in the soil. The total increase in carbon was $31.8 \mathrm{t} \mathrm{C/ha} \mathrm{compared} \mathrm{with} \mathrm{the} \mathrm{baseline} \mathrm{(pure} \mathrm{Imperata} \mathrm{grasslands} \mathrm{with} \mathrm{hardly}$ any remaining trees; see Figure 2 ). The trees had a heterogeneous age structure, varying from one to four years old. This heterogeneity was partly caused by the planting contracts of the VCM programme, which were spread over several years (2009-13). In addition, the initial challenges to the leadership caused a delay in planting, as did the delay in handing over seedlings. This was compounded by the effects of El Niño (2009-10), which killed many trees. To accommodate for the different ages and planting densities, sample plots were set up that represented all variations. Despite the initial challenges, the rate of biomass accumulation needed to achieve the carbon sequestration targets of the clients remains on track, especially since the trees are not expected to show their largest gains in biomass until three to four years from now. The adoption of ANR practices proved to be an important component to achieve carbon sequestration targets.

\section{Figure 2. Carbon stock per ha on Imperata grasslands after three years}

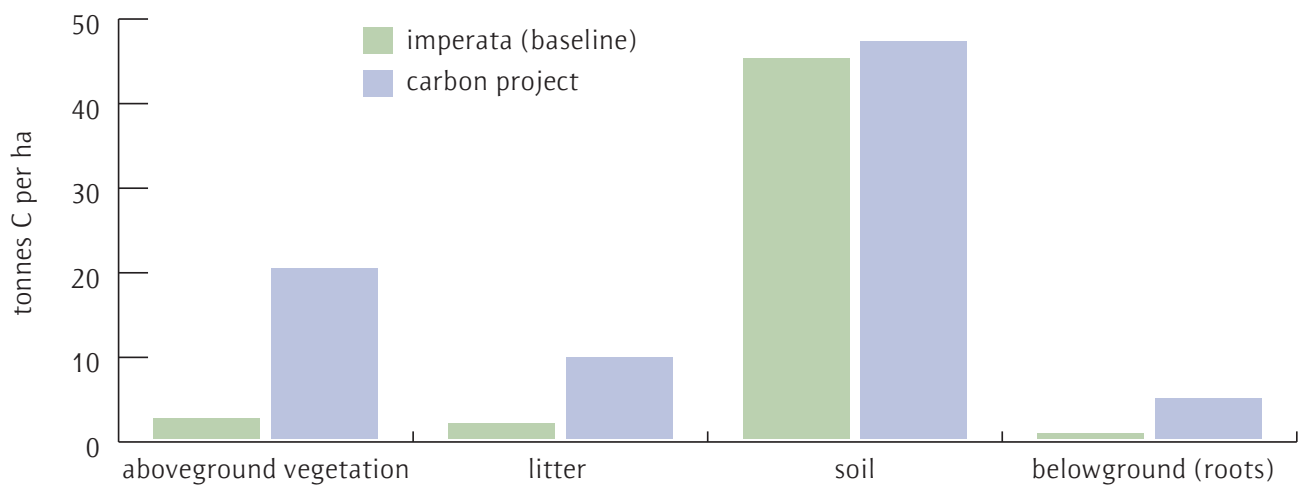

Source: Baseline situation: taken from Lusiana et al. (2005). 


\section{Assisted natural regeneration}

\section{Accelerating carbon sequestration}

The usual regeneration practice carried out by the project consisted of opening up Imperata grasslands by slashing, uprooting and clean-weeding, followed by planting trees. This caused the bare soil to dry out quickly, a problem aggravated by the drought period caused by El Niño in 1999-2000.

Early in 2012, FAO began looking for options to field-test ANR as a low-cost option to restore forests on degraded lands. $\mathrm{CO}^{2}$ Operate BV was selected to test ANR in Indonesia; the FAO project is also carried out in the Philippines, Laos and Thailand. With ANR, Imperata grasses are no longer uprooted and removed, but simply pressed flat with a wooden plank. Small tree seedlings, commonly found in between the grasses, are protected and can grow, as competition for light no longer suppresses their growth. This practice has improved tree growth of the natural occurring trees and planted trees beyond expectations, providing quick gains in carbon stocks. Farmers were enthusiastic about the ANR practices, especially in combination with economical valuable agroforestry trees, which are given a favourable micro-climate by the fast-growing indigenous trees under ANR treatment. The pressed Imperata grasses form a thick blanket, which reduces soil temperatures and keeps the soil moist, even after a dry period lasting five to six weeks. Farmers talk about tanah dingin (cold soil), referring to the moisture content and hence the slightly lower soil temperatures. The decaying Imperata provides additional carbon to the soil.

\section{Lessons learned}

Since the project began in 2010, a number of challenges have been overcome. A workable governance structure is now in place, along with innovative technology. Using ANR and tree planting, rehabilitation occurs much faster compared to natural forest restoration in Imperata grasslands. A study by Yassir, Van der Kamp and Buurman (2009), shows that it could take at least nine years before Imperata disappears under natural forest regeneration, or even longer if fires occur. Since the VCM activities began, not one fire has occurred, suggesting that people have become more careful with their environment. The approach has proved to be a practical way for communities to engage in collective action to restore degraded landscapes.

\section{Adaptive institutional arrangements}

Although indigenous practices and laws are often championed for their ability to achieve development and sustainability goals, more formal rules and organizational structures may be needed when implementing a performance-based activity such as a carbon sequestration programme. Under the right conditions, collective action could be a good option in a context where community-based management is well embedded. However, this 
approach will work only if all cooperatives participate equally and fairly. All members must feel free to discuss any matter that will help to improve the performance of restoration activities.

\section{Carbon sequestration}

ANR has the potential to speed up carbon sequestration in the initial years of a carbon sequestration programme, both above and below ground. As an isolated activity, ANR does not provide a large enough incentive to restore degraded landscapes in the Sumatran context. However, if ANR is combined with schemes that generate short-term benefits (such as carbon payments or short rotation crops) and longer-term economic benefits (for instance, from harvestable agroforestry trees), it can be very effective.

Participating farmers need to have a full understanding of carbon sequestration and carbon trading. Once they better understand carbon benefits, they begin to protect existing trees in their fields, knowing that the trees hold their value as long as they are not cut down and provide good conditions for agroforestry. It also helps to stimulate the understanding of the importance of ANR. Understanding carbon sequestration and the carbon market is therefore an important subject for training sessions.

\section{Restoration of ecosystem services and biodiversity}

Although the restored areas are still relatively small ( $55 \mathrm{ha}$, but with an additional 20 ha as of June 2014), the farmers already see environmental benefits. After ANR treatment the soil remains moist for a long time, which helps the trees grow. At a larger scale, ANR is expected to be able to regulate the water supplies for irrigation of the ricefields in the valley. Another change is the fact that after almost 40 years, more and more plants and animals are returning to the rehabilitated agroforestry areas. Birds, monkeys, wild boar, small and large deer are seen regularly. Although they eat the leaves of the growing trees, this has not caused problems to date. The areas are also increasingly used as a corridor between forested areas, judging from the many animal tracks that are seen.

$\mathrm{CO}^{2}$ Operate continues to work in West Sumatra with local partners and has started to scale up landscape restoration activities. The methodology is now integrated into the West Sumatra government programme, as part of a benefit-sharing mechanism that is part of REDD+ activities.

\section{References}

Lusiana, B., M. van Noordwijk and S. Rahayu. 2005. Carbon stocks in Nunukan, East Kalimantan: a spatial monitoring and modelling approach. Report from the carbon monitoring team of the Forest Resources Management for Carbon Sequestration (FORMACS) project.

von Benda-Beckmann, F. and K. von Benda-Beckmann. 2004. Struggles over Communal Property Rights and Law in Minangkabau, West Sumatra. Max Planck Institute for Social Anthropology, Halle/Saale. Working Paper No. 64.

Yassir, I., J. van der Kamp and P. Buurman. 2010. "Secondary succession after fire in Imperata grasslands of East Kalimantan, Indonesia." Agriculture, Ecosystems and Environment 137: 172-182. 